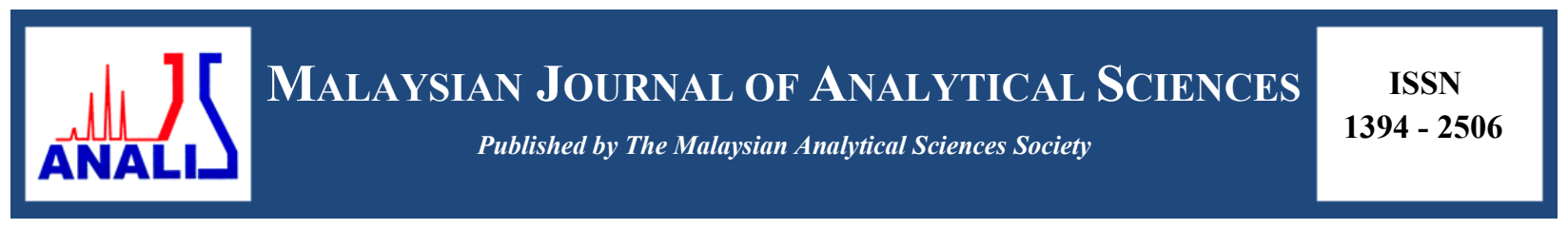

\title{
DEGRADATION OF IMAZAPYR AND IMAZAPIC IN AQUEOUS SOLUTIONS AND SOIL UNDER DIRECT SUNLIGHT
}

\author{
(Degradasi Imazapyr dan Imazapic dalam Larutan Akueus dan Tanah di bawah Cahaya \\ Matahari)
}

Siti Norashikin Mohamad Shaifuddin ${ }^{1}$, Hazilia Hussain ${ }^{1 *}$, Hamzah Fansuri Hassan ${ }^{2}$, Nazri Che Dom ${ }^{1}$, Razi Ikhwan Md Rashid ${ }^{1}$

${ }^{I}$ Department of Environmental Health and Safety

${ }^{2}$ Department of Basic Sciences, Faculty of Health Sciences

Universiti Teknologi MARA, 42300 UiTM Puncak Alam, Selangor, Malaysia

*Corresponding author: hazilia@puncakalam.uitm.edu.my

Received: 25 January 2017; Accepted: 3 July 2017

\begin{abstract}
Photolytic degradation of imazapyr and imazapic in aqueous solutions ( $\mathrm{pH} \mathrm{3,7}$ and 9) and soil under direct sunlight were studied. A total of $0.1 \mathrm{~mL}$ of aqueous solutions containing herbicides were collected at $0,1,2$ and 3 days and were directly analyzed using high performance liquid chromatography equipped with ultraviolet detector (HPLC-UV) without further clean-up process. Soils that were treated with herbicides were sampled at seven different days $(0,1,5,10,16,23$ and 30$)$. The photolytic results showed that imazapyr and imazapic degraded faster in solutions compared to soils ( $>90 \%)$. Photolysis of imidazolinone herbicides became more effective as the $\mathrm{pH}$ value increased. The half-lives for imazapyr and imazapic degradation on soil surface under sunlight were calculated at 126 days and 85.56 days, respectively. Low degradation of imazapyr and imazapic in soil becomes a concern since it may contribute to the persistency of imidazolinone herbicides in this media. The use of these herbicides should be planned well to reduce the risk of herbicides leaching into groundwater and posing risk to non-target crops and organism.
\end{abstract}

Keywords: photolysis, imazapyr, imazapic, aqueous solutions, soil

Abstrak

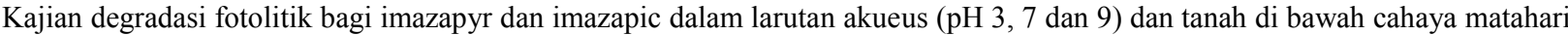
telah dijalankan. Sebanyak $0.1 \mathrm{~mL}$ cecair larutan yang mengandungi racun rumpai telah diambil pada hari 0,1,2 dan 3 dan terus dianalisis menggunakan kromatografi cecair berprestasi tinggi dengan pengesan ultra-ungu (HPLC-UV) tanpa melalui sebarang proses pembersihan. Tanah yang telah dicampurkan dengan racun rumpai telah disampelkan pada tujuh hari yang berbeza $(0,1$, 5, 10, 16, 23 dan 30). Keputusan fotolitik menunjukkan imazapyr dan imazapic lebih cepat terurai di dalam cecair berbanding dengan tanah $(>90 \%)$. Fotolisis racun rumpai imidazolinon adalah lebih berkesan apabila pH meningkat. Jangka masa separuh hayat untuk imazapyr dan imazapic terurai di permukaan tanah di bawah cahaya matahari masing-masing adalah 126 dan 85.56 hari. Degradasi rendah bagi imazapyr dan imazapic dalam tanah telah menjadi suatu kebimbangan kerana ia boleh menyumbang kepada pengekalan racun rumpai imidazolinon di dalam media ini. Penggunaan racun rumpai ini perlu dirancang dengan sebaiknya bagi mengurangkan risiko untuk racun larut terlesap ke dalam air bawah tanah dan menimbulkan risiko kepada tanaman dan organisma yang bukan sasarannya.

Kata kunci: fotolisis, imazapyr, imazapic, larutan akueus, tanah 


\section{Siti Norashikin et al: DEGRADATION OF IMAZAPYR AND IMAZAPIC IN AQUEOUS SOLUTIONS AND SOIL UNDER DIRECT SUNLIGHT}

\section{Introduction}

As one of the main contributors to Malaysian economy, the agriculture sector takes up a major part of the land used in this country [1]. Additionally, Malaysian government has invested millions of ringgit to ensure this sector is well developed and this includes introducing modern agricultural input such as herbicides [2]. This contributes to the increase of herbicide application in Malaysian agricultural areas [1]. Herbicide is the most common method used to prevent or control the unwanted weeds in agricultural areas. Not only that, it is also used to maintain the quality of crops and reduce the percentage of yield losses [2]. Some common examples of herbicides are 2,4-D dimethylamine, paraquat, glyphosate and propanil [1]. However, the use of herbicide is harmful in certain quantities as some herbicides may leach into the root zone once they are introduced into the environment. Consequently, this can either result in better weed control or cause damage to surrounding environment as not all of the applied chemicals are able to reach the target site [3]. Therefore, it is very important to understand the fate of the chemicals in the environment.

Currently, commercial herbicides containing two active ingredients (imazapyr and imazapic) are widely used in rice field area to control the growth of weedy rice $[4,5]$. The growth of weedy rice in rice field affects the annual rice yield in Malaysia [2,6] and this contributes to economic loss among farmers [3]. Thus, the combination of imidazolinone-tolerant rice (IMI-TR) seeds developed by MARDI and BASF (Malaysia) with a single application of imazapyr/ imazapic in rice field area $[4,5]$ are found to be able to reduce weed management cost and yield higher quality of rice [6]. Imazapyr and imazapic belong to imidazolinone group that can eliminate subjected weeds by inhibiting the action of plant enzyme acetohydroxyacid synthase (AHAS) and interfering with their growth $[7,8]$.

The applications of imidazolinone herbicides are assumed to be environmentally safe because of their low toxicity effects on mammals as well as being highly effective with a very low application rate $[4,9,10]$. This in turn reduces the amount of herbicides released into the environment and ecosystem [6]. However, the application of herbicides in rice field for a long period of time may give rise to several environmental issues. One of the environmental concerns is the persistency of imidazolinone herbicide in soil [11 - 14] and groundwater [15]. Since these herbicides are able to remain for a long period of time in the environment, it may pose risks to non-target organisms such as fish [16, 17].

There are many factors affecting the persistency of herbicides molecule in the environment and these may include sorption, volatilisation, leaching and degradation (abiotic and biotic) [3, 14]. Photodegradation may play an important role for the breakdown of herbicides in environment because all pesticides are susceptible to this process to a certain degree [3]. Since imazapyr and imazapic are applied to foliage or soil surface, they are more prone to break down by sunlight [3]. Therefore, the aims of this study were to determine the capability of imazapyr and imazapic herbicides to break down under direct sunlight as well as to calculate their half-life in aqueous solutions and soil surface.

\section{Chemicals}

\section{Materials and Methods}

Imazapyr and imazapic with $99.5 \%$ and $99.9 \%$ purity respectively were purchased from Active Advance Technology Company. Acetonitrile ( $\mathrm{ACN}$ ) grade for liquid chromatography (LC), acetic acid, monopotassium phosphate and sodium hydroxide $(\mathrm{NaOH})$ were obtained from Merck (Malaysia). Potassium biphthalate, borax and hydrochloric acid $(\mathrm{HCl})$ were purchased from Juara Saintifik (Malaysia). Imazapyr and imazapic solutions were prepared by dissolving the weighed herbicide in $\mathrm{ACN}$.

\section{Preparation of buffer solutions}

Three different buffer solutions ( $\mathrm{pH} \mathrm{3,7}$ and 9) were prepared based on United States Environmental Protection Agency's (USEPA) Fate, Transport and Transformation Test Guidelines [18]. The buffer solutions were prepared by mixing $0.1 \mathrm{~N} \mathrm{HCl}$ with $0.1 \mathrm{M}$ potassium biphthalate $(\mathrm{pH} 3) ; 0.1 \mathrm{~N} \mathrm{NaOH}$ with monopotassium phosphate (pH 7); and $0.025 \mathrm{M}$ borax with $0.1 \mathrm{~N} \mathrm{HCl}$ for $\mathrm{pH}$ 9. All buffers solutions and glassware used in this experiment were sterilised by using autoclave [9]. 


\section{Photolysis of imazapyr and imazapic in aqueous solutions}

Outdoor photodegradation experiments for imazapyr and imazapic in aqueous solutions and soil were conducted in greenhouse at Universiti Teknologi MARA Puncak Alam Campus. The photolysis activity was tested for individual and mixture of the herbicides using USEPA protocol [19]. All three prepared buffer solutions were then treated with herbicide solution in order to obtain $10 \mu \mathrm{g} \mathrm{mL}^{-1}$ of imazapyr and imazapic concentration respectively as well as a mixture of imazapyr and imazapic in the ratio of 1:3.10 mL buffered solutions of herbicide (pH 3,7 and 9) were placed in three different sterilized glass test tubes before being exposed under sunlight. All these solutions were prepared in triplicate along with two control samples. The average temperatures during experimental days were varied between $26^{\circ} \mathrm{C}$ to $36^{\circ} \mathrm{C}$. The sunlight intensity was also measured during the exposure. An amount of $0.1 \mathrm{~mL}$ of aliquots was pipetted aseptically from each test tube on day $0,1,2$ and 3 into $2 \mathrm{~mL}$ amber vials for further analysis with High Performance Liquid Chromatography (HPLC) [20].

\section{Photodegradation of imazapyr and imazapic on soil}

For this research, the study of photodegradation on soil surface was carried out in reference to USEPA Guideline [21]. A soil sample was collected from the surface layer $(0$ to $10 \mathrm{~cm})$ from the field. The sample was air-dried at room temperature, passed through $2 \mathrm{~mm}$ sieve and was later autoclaved at $121^{\circ} \mathrm{C}$ twice [9]. An amount 5 grams of sterilized soil was weighed into sterile petri dish and herbicide solution was applied on the top of spread soil to obtain the initial concentration of $5 \mu \mathrm{g} \mathrm{g}^{-1}$. For control samples, the petri dishes containing soil-herbicide were wrapped with aluminum foil to keep out light and maintain darkness. The samples were exposed to the sunlight and then were collected at $0,1,5,10,16,23$ and 30 days. Three exposed and control samples were sampled for each sampling day and transferred into sterile centrifuge tube for herbicides extraction. Herbicides were extracted from the soil samples by shaking $20 \mathrm{~mL}$ of $0.5 \mathrm{M} \mathrm{NaOH}$ and centrifuging at $2000 \mathrm{rpm}$ for 10 minutes. These steps were repeated twice. The decanted supernatants were filtered through $0.45 \mu \mathrm{m}$ filter and were analyzed directly using HPLC [20].

\section{HPLC analysis}

An Agilent 1200 High Performance Liquid Chromatography equipped with UV detector was used for quantification of imazapyr and imazapic residues [20]. The wavelength for the detector was set up at $251 \mathrm{~nm}$. ACN: acidified water $(\mathrm{pH} 2.88)(35: 65, \mathrm{v} / \mathrm{v})$ was used as mobile phase with flow rate of $1.0 \mathrm{~mL} \mathrm{~min}{ }^{-1}$ while for chromatography, An Agilent Zorbax SB-C18 column (4.6 mm i.d. x $250 \mathrm{~mm}, 5 \mu \mathrm{m})$ was used.

\section{Data analysis}

The percentages of imazapyr and imazapic degradation were calculated using equation 1 [22]:

$$
\text { Photodegradation }(\%)=\left(\mathrm{C}_{0}-\mathrm{C}_{\mathrm{t}}\right) / \mathrm{C}_{0} \times 100 \%
$$

Calculations for imidazolinone herbicides half-life were performed using kinetic equation 2 and 3, respectively $[9,19,23]$ :

$$
\begin{aligned}
& \ln \left(\mathrm{C}_{0} / \mathrm{C}_{\mathrm{t}}\right)=\mathrm{kt} \\
& \mathrm{t}_{1 / 2}=0.693 / \mathrm{k}
\end{aligned}
$$

where, $\mathrm{C}_{0}$ refers to the initial concentration of herbicide, $\mathrm{C}_{\mathrm{t}}$ represents the herbicide concentration at time $t, \mathrm{k}$ is photolytic rate constant, and $\mathrm{t}_{1 / 2}$ exemplifies the half-life.

\section{Photolysis of imidazolinone herbicides in aqueous solutions}

\section{Results and Discussion}

The results for degradation of imidazolinone herbicides in aqueous solutions were shown in Table 1. These findings suggested that both imazapyr and imazapic herbicides were able to completely degrade $(>90 \%)$ within 72 hours under direct sunlight (light intensity ranged 162 to $1059 \mathrm{watt} / \mathrm{m}^{2}$ ). The half-life values of imazapyr under direct sunlight were 16.54 hours ( $\mathrm{pH} 3), 12.42$ hours $(\mathrm{pH} 7)$ and 12.18 hours ( $\mathrm{pH} 9)$. Imazapic was found to have halflives of 32.35 hours, 10.06 hours and 10.76 hours in $\mathrm{pH} \mathrm{3,7}$ and 9, respectively. Trials on combination of both 
herbicides under acidic $\mathrm{pH}$ level showed that imazapyr was completely degraded within 24 hours while imazapic residue was calculated at 20.94 percent within 72 hours.

Table 1. Photolysis of imidazolinone herbicides under direct sunlight in buffer solutions

\begin{tabular}{|c|c|c|c|c|c|c|c|c|c|}
\hline \multirow{3}{*}{$\begin{array}{l}\text { Sampling Days } \\
\text { Herbicide } \\
\text { pH solution }\end{array}$} & \multicolumn{9}{|c|}{ Percentage of Residues (\%) } \\
\hline & \multicolumn{3}{|c|}{ Imazapyr } & \multicolumn{3}{|c|}{ Imazapic } & \multicolumn{3}{|c|}{ Imazapyr: Imazapic (1:3) } \\
\hline & 3 & 7 & 9 & 3 & 7 & 9 & 3 & 7 & 9 \\
\hline 0 & 100 & 100 & 100 & 100 & 100 & 100 & 100:100 & 100:100 & 100:100 \\
\hline 1 & 65.87 & 23.73 & 23.69 & 55.89 & 17.42 & 17.09 & $0: 51.76$ & $25.29: 16.80$ & $26.03: 17.39$ \\
\hline 2 & 15.98 & 5.01 & 4.09 & 28.83 & 5.91 & 2.10 & $0: 30.29$ & $4.04: 2.16$ & $4.74: 2.74$ \\
\hline 3 & 4.89 & 1.80 & 1.67 & 21.38 & 0.72 & 0.97 & $0: 20.94$ & $1.39: 0.88$ & $1.68: 1.08$ \\
\hline
\end{tabular}

Results presented in Table 1 suggested that $\mathrm{pH}$ values of buffer solutions affected the photolysis rate for imazapyr and imazapic. Degradation rate of imidazolinone herbicides tested increased as $\mathrm{pH}$ increased, which was in agreement with previous studies [23, 24, 25]. This might be due to the effect of higher molar absorption coefficients at higher $\mathrm{pH}$ value [24]. Imazapyr and imazapic herbicides were more rapidly degraded in solution compared to on soil surface (Table 1 and Table 2). However, the photolysis rate of imidazolinone herbicides in actual water samples might be slower due to the presence of light screening compounds such as humic acid and natural organic matter (NOM) [3, 26].

\section{Photodegradation of imidazolinone herbicides on soil}

The percentages of photodegradation of two imidazolinone herbicides were tabulated in Table 2. Imazapic had a higher degradation rate $\left(t_{1 / 2}=85.56\right.$ days $)$ compared to imazapyr $\left(t_{1 / 2}=126\right.$ days). The ability of these herbicides to remain longer might be due to the properties of the soil itself which absorbed the photons, therefore reducing the availability of photons to degrade the herbicides compounds [9,27]. Previous study showed that imazapyr and imazapic had an enhanced adsorption and a lower desorption in rice field soil due to the presence of high clay content and organic matter [28], especially at low $\mathrm{pH}$ value. The soil sample used consisted of $57.50 \%$ clay, $37.50 \%$ silt, $0.90 \%$ sand, $4.26 \%$ total organic carbon and a pH of 5.29. Since the soil sample used in this study had the properties of high clay content and organic matter which were similar to a previous study [28], it suggested that these two imidazolinone herbicides were tightly bound to soil particles. This indicated that very little of these compounds were available for degradation via photolytic activity. Moreover, air-drying step of soil sample preparation in this study might cause an increase in soil-herbicide binding as the soil water content decreased [27]. Once the herbicides penetrated underneath the soil surface, the photodegradation activity became low [27] and this might contribute to their persistency in the environment. Since imazapyr and imazapic were able to remain longer in the soil, these herbicides also had a higher probability to leach into groundwater as reported previously [14, 29].

Table 2. Photodegradation of imidazolinone herbicides on soil exposed with direct sunlight

\begin{tabular}{lccc}
\hline Sampling Days & \multicolumn{3}{c}{ Percentage of Residues (\%) } \\
\hline Herbicide & Imazapyr & Imazapic & Imazapyr: Imazapic (1:3) \\
\hline 0 & 100 & 100 & $100: 100$ \\
1 & 98.24 & 92.77 & $98.69: 97.07$ \\
5 & 96.99 & 90.88 & $95.25: 94.20$ \\
10 & 94.52 & 87.66 & $93.58: 93.25$ \\
16 & 93.18 & 83.03 & $91.30: 92.01$ \\
23 & 92.04 & 81.03 & $87.73: 83.53$ \\
30 & 84.75 & 78.40 & $78.12: 81.16$ \\
\hline
\end{tabular}




\section{Conclusion}

Photodegradation of imidazolinone herbicides could be an important factor for their breakdown in the environment as demonstrated in the tabulated results. Degradation of imazapyr and imazapic in aqueous solutions were faster compared to on soil surface under direct sunlight. Low photolytic degradation in soil became a concern since it might pose risk to non-target crops and organisms. Further study on biotic degradation might expand new angle in this field since microbe could be used as a degrading organism to break down imidazolinone herbicides, especially under anaerobic condition. The approach in this paper could be taken as a general applied method to analyses other degraded pollutants, especially those that had similar functional group.

\section{Acknowledgement}

The authors would like to acknowledge the research grant from Universiti Teknologi MARA (LESTARI 21/2016) for supporting this research.

\section{References}

1. Ismail, B. S., Sameni, M. and Halimah, M. (2011). Evaluation of herbicide pollution in the Kerian ricefields of Perak. Malaysia. World Applied Sciences Journal, 15(1): 5 - 13.

2. Fuad, M. J., Junaidi, A. B., Habibah, A., Hamzah, J., Toriman, M. E., Lyndon, N., Er, A. C., Selvadurai, S. and Azima, A. M. (2012). The impact of pesticides on paddy farmers and ecosystem. Advances in Natural and Applied Sciences, 6(1): $65-70$.

3. Tiryaki, O. and Temur, C. (2010). The fate of pesticide in the environment. Journal of Biological \& Environmental Sciences, 4(10): 29 - 38.

4. Azmi, M., Azlan, S., Yim, K. M., George, T. V. and Chew, S. E. (2012). Control of weedy paddy in directseeded paddy using the clearfield production system in Malaysia. Pakistan Journal of Weed Sciences Research, 18: $49-53$.

5. Idris, R. (2012). Dua gen baru dihasilkan MARDI akhiri belenggu padi angin. http://www.bharian.com.my/ articles/DuagenbarudihasilkanMARDIakhiribelenggupadiangin/Article/print_html. [Access online 19 December 2012].

6. Hidayatul, N., Anusar, S., Mazlan, N., Ahmad, E., Engku, K., Juraimi, A. S. and Yusop, M. R. (2014). Comparative study of vegetation and reproductive growth. Journal of International Society for Southeast Asian Agricultural Sciences, 20(1): $41-51$.

7. Hess, F. G., Harris, J. E., Pendino, K. and Ponnock, K. (2001). Imidazolinone. In: handbook of pesticide toxicology. Academic Press, San Diego: pp. $1641-1651$.

8. Colquhoun, J. (2001). How herbicides work: Uptake, translocation, and mode of action. http://osuext.intermountaintech.org/download/how herbicides work.pdf. [Access online 18 December 2012].

9. Ramezani, M., Oliver, D. P., Kookana, R. S., Gill, G. and Preston, C. (2008). Abiotic degradation (photodegradation and hydrolysis) of imidazolinone herbicides. Journal of Environmental Science and Health, Part B: Pesticides, Food Contaminants, and Agricultural Wastes, 43(2): $105-112$.

10. Tan, S., Evans, R. R., Dahmer, M. L., Singh, B. K. and Shaner, D. L. (2005). Imidazolinone-tolerant crops: History, current status and future. Pest Management Science, 61: $246-257$.

11. Rotterdam Convention (2001). Interim secretariat for rotterdam convention on the prior informed consent procedure for certain hazardous chemicals and pesticides in international trade - PIC CIRCULAR XIV. http://www.pic.int/Portals/5/en/Circular/CIRC14EN.pdf. [Access online 13 February 2013].

12. Carrier, M., Perol, N., Herrmann, J.-M., Bordes, C., Horikoshi, S., Paisse, J. O., Baudot, R. and Guillard, C. (2006). Kinetics and reactional pathway of imazapyr photocatalytic degradation influence of $\mathrm{ph}$ and metallic ions. Applied Catalysis B: Environmental, 65: $11-20$.

13. Bundt, A. C., Avila, L. A., Pivetta, A., Agostinetto, D., Dick, D. P. and Burauel, P. (2015). Imidazolinone degradation in soil in response to application history. Planta Daninha, 33(2): $341-349$.

14. Souza, M. F., Neto, M. D. C., Marinho, M. I., Saraiva, D. T., Faria, A. T., Silva, A. A. and Silva, D. V. (2016). Persistence of imidazolinones in soils under a clearfield system of rice cultivation. Planta Daninha, 34(3): 589 $-596$.

15. Börjesson, E., Torstensson, L. and Stenström, J. (2004). The fate of imazapyr in a Swedish railway embankment. Pest Management Science, 60 (6): 544 - 549. 
16. Moraes, B. S., Clasen, B., Loro, V. L., Pretto, A., Toni, C., Antonio de Avila, L., Marchesan, E., Luiz de Oliveira Machado, S., Zanella, R. and Reimche, G. B. (2011). Toxicological response of Cyprinus Carpio after exposure to a commercial herbicide containing imazethapyr and imazapic. Ecotoxicology and Environmental Safety, 74: $328-335$.

17. Golombieski, J. I., Sutili, F. J., Salbego, J., Seben, D., Gressler, L. T., da Cunha, J. A., Gressler, L. T., Zanella, R., Vaucher, R. A., Marchesan, E. and Baldisserotto, B. (2016). Imazapyr+imazapic herbicide determines acute toxicity in silver catfish Rhamdia quelen. Ecotoxicology and Environmental Safety, 128 (2016): 91 - 99.

18. United States Environmental Protection Agency (2008). Fate, transport and transformation test guidelines. EPA 712-C-08-012; Prevention, pesticides and toxic substances (7101). OPPTS 835.2120 hydrolysis. https://www.regulations.gov/document?D=EPA-HQ-OPPT-2009-0152-0009. [Access online 1 January 2014].

19. United States Environmental Protection Agency (1998). Fate, transport and transformation test guidelines. EPA 712-C-98-060; Prevention, pesticides and toxic substances (7101). OPPTS 835.2210 Direct photolysis rate in water by sunlight. https://www.regulations.gov/document?D=EPA-HQ-OPPT-2009-0152-0011. [Access online 1 January 2014].

20. Shaifuddin, S. N. M., Hussain, H. and Hassan, H. F. (2016). Optimization of extraction and detection method for imazapyr and imazapic residues in water, soil and fish tissue samples using high performance liquid chromatography. Jurnal Teknologi, 78(6-7): 43 - 48.

21. United States Environmental Protection Agency (USEPA). (2008). Fate, transport and transformation test guidelines. EPA 712-C-08-015; Prevention, pesticides and toxic substances (7101). OPPTS 835.2410 photodegradation on soil. https://www.regulations.gov/document?D=EPA-HQ-OPPT-2009-0152-0015. [Access online 1 January 2014].

22. Abdullah, A. H., Peng, W. T. and Hussein, M. Z. (2016). Degradation of methylene blue dye by $\mathrm{CuO}-\mathrm{BiVO}_{4}$ photocatalysts under visible light irradation. Malaysian Journal of Analytical Sciences, 20(6): 1338 - 1345.

23. Harir, M., Gaspar, A., Frommberger, M., Lucio, M., El Azzouzi, M., Martens, D., Kettrup, A. and SchmittKopplin, P. (2007). Photolysis pathway of imazapic in aqueous solution: Ultrahigh resolution mass spectrometry analysis on intermediates. Journal of Agricultural and Food Chemistry, 55(24): 9936 - 9943.

24. Pandiselvi, V., Sathiyanarayanan, S., Ayyappan, S. and Ramesh, A. (2012). Investigations on the photolysis of imazethapyr in aqueous solutions under direct sunlight by HPLC UV and LC-MS/MS-ESI - application of green alga as a potential biomarker. International Journal of Chemistry Research, 3(1): $45-51$.

25. Mallipudi, N. M., Stout, S. J., da Cunha, A. R. and Lee, A. (1991). Photolysis of imazapyr (AC 243997) herbicide in aqueous media. Journal of Agricultural and Food Chemistry, 39(2): 412 - 417.

26. Espy, R., Pelton, E., Opseth, A., Kasprisin, J. and Nienow, A. M. (2011). Photodegradation of the herbicide imazethapyr in aqueous solution: Effects of wavelength, $\mathrm{pH}$, and natural organic matter (NOM) and analysis of photoproducts. Journal of Agricultural and Food Chemistry, 59: 7277 - 7285.

27. Curran, W. S., Loux, M. M., Liebl, R. A. and Simmons, F. W. (1992). Photolysis of imidazolinone herbicides in aqueous solution and on soil. Weed Science, 40: $143-148$.

28. Shaifuddin, S. N. M., Hussain, H., Hassan, H. F., Dom, N. C. and Rashid, R. I. M. (2016). Adsorption and desorption of imazapyr and imazapic in soils. http://learningdistance.org/rcstss2016/public/site/ rcstss2016_abstracts_ST_final_secured.pdf. [Access online 2 January 2017].

29. Mazlan, A. Z., Hussain, H. and Zawawi, M. A. M. (2016). Assessment of imazapic presence in surface water and groundwater in paddy field area. Jurnal Teknologi, 78(5-5): $33-37$. 